\title{
RATIONALE SET OF INDICATORS AND PRIORITIZE RELEVANT TO ASSESS COMPETITIVE ACTIVITY OF HOCKEY PLAYERS OF HIGH QUALIFICATION OF DIFFERENT ROLES
}

\author{
Mikhnov A.P.
}

National University of Physical Education and Sport of Ukraine

\begin{abstract}
Annotation. Purpose: organize technical and tactical actions and determine their priority importance for high-end players of different roles. Establish their priority importance for the success of competitive activity hockey with the game roles. Material: the study involved 54 experts on hockey coaches and players of high class. The significance of technical and tactical actions evaluated for players of different roles. Results: systematic account of technical and tactical actions of athletes and prioritize them to assess the significance of competitive activity. Three groups of technical and tactical actions: 1) active attacks; 2) - active safety; 3) - organizational and maneuvering. Set priorities for technical and tactical actions for players of different roles. Conclusions: the proposed technical and tactical actions can be recommended for the evaluation of the effectiveness of competitive activity players. In the process of estimating the action game players need to consider their role playing. Identification of priority in the implementation of technical and tactical actions in the game can be used in integrated assessment of actions players different roles.
\end{abstract}

Keywords: competitive, activities, technique, tactics, reliability index, indicator of success.

\section{Introduction}

Perfection of management of competition functioning on the base of objectification of knowledge about its structure and provisioning components is one of the most important tasks of sportsmen training system's formation in game kinds of sports $[5,6,7,11,17,20]$.

Prestige character and popularity of sport games, their high level of competitiveness at international sport arena and importance of sport result are so evident that urgency of questions, connected with increasing of competition functioning's effectiveness is out of the question [1-3,12-15,19].

One of the most important problems in sport games in general and in hockey in particular is evaluation of competition functioning. Total sport result of a collective does not always permits to reflect competition functioning of separate players $[4,8,9,18]$.

Active counter action of adversary requires instant change of previously worked out plan of individual hockey player's and team's actions. Sportsmen have to act in conditions of expressed deficit of time with changes of game situation and demand in adequate response [10].

For evaluation of actions in match specialists consider qualitative and quantitative characteristics of technical tactic actions. Such actions are means of realization of sport duel's tasks and they also serve as the most informative criteria, permitting to reflect sportsman's behavior in match and effectiveness of his actions [8,16]. However, with it, it is necessary to consider the fact that hockey players of different roles have different priorities in realization of different tasks in match.

Thus, in present research we have tried to systemize technical tactic actions, fulfilled by hockey players in competition functioning and to determine their priority importance for hockey players of different roles. The work has been fulfilled in the frames of scientific research topic 2.4. "Theoretical methodic principles and individualization of training process in game kinds of sports" in compliance with combined plan of SRW in sphere of physical culture and sports for 2011-2015.

Purpose, tasks of the work, material and methods

The purpose of the work is to systemize technical tactic actions and determine of their priority significance for highly qualified hockey players of different roles.

The tasks of the research were to determine and systemize technical tactic actions, offered by specialists for evaluation of competition functioning, determination of their priority significance for successful competition functioning of highly qualified hockey players, considering their roles in match.

The methods of the research: pedagogic observation and generalization of special scientific-methodic literature data, expert questioning, analysis of Internet data. In researches 54 experts participated, who, in order of priority, determined significance of technical tactic actions for hockey players of different roles.

Results of the research

Analysis of special scientific-methodic literature and questioning of hockey experts showed that in competition functioning hockey players fulfill great number of different technical-tactic actions and every of them influence on sport duel's process and can, to some or other extent, influence on its result.

In total more than thirty separate match actions were marked out, which can be conventionally divided (for systemizing) into three main groups (see fig.1) Detail grouping and differentiation were determined by sense similarity of actions and their relation to different phases of match.

So, in separate group we can mark out those technical-tactic actions, which are oriented on active attack of adversary's net and sharpening of attacking phase - group of active attacking actions.

\footnotetext{
(C) Mikhnov A.P., 2015

http://dx.doi.org/10.15561/20755279.2015.0105
} 


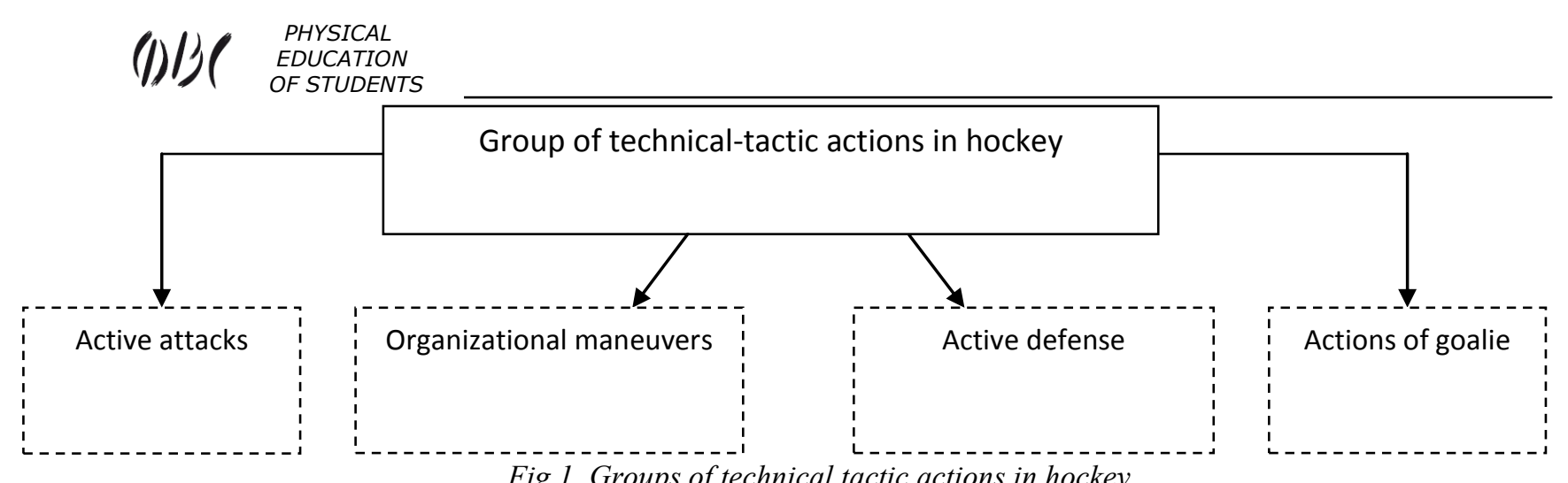

Fig. 1. Groups of technical tactic actions in hockey

The second group contains technical-tactic actions, oriented on organization of hockey players' actions and their skating on field, maneuvering and current interaction, i.e. organizational-maneuvering actions.

The third group (active defensive actions) consists of hockey players' actions, oriented on defense of net and active picking up of puck.

Technical-tactic actions, fulfilled by goalie can be marked out in separate group - game of hockey goalie.

So, among active attacking actions experts offer to mark out throws in hockey net, thrown in pucks, efficient passes, duels with adversary's goalie. Besides, to day indicator of gained scores (sum of thrown in pucks) is used as important indicator for highly qualified hockey players.

Group of organizational-maneuvering actions contains the most of actions, which can be fulfilled both in phase of defense and in phase of attack.

In this group, among main technical-tactic actions the following can be marked out: dribbling of puck, maneuvering on skates, cheating of adversary (by long trajectory, short, with strength), passes of puck (excluding efficient), catching of puck by body, coming out of adversary's guiding, choosing of position and etc.

This group can also include fight of hockey players at throw of puck on field because successful or unsuccessful start can influence on further organizational actions of team.

The third group - active defensive actions - includes the following: picking up of puck, power fight, repelling of puck and etc.

Besides, specialists offer to mark out a number of indicators, which characterize effectiveness of competition functioning of goalie. These indicators in general characterize successfulness of repelling of pucks from net. As informative indicators they mark out the following: quantity of throws in net, quantity of missed pucks, percentage of missed pucks, index of reliability (integral index of match's effectiveness).

As a result of questioning experts marked out and offered to use in our further researches the following informative technical-tactic actions and indicators of hockey players: fulfilled throws in net; thrown in pucks; percentage of throws' realization; quantity of power techniques; penalty minutes for violation of rules; efficient passes, successful throws of puck on field; pucks, repelled from net; picking ups of pucks; realized obstacles for goalkeeper; support of partner; loss of puck; gained scores; indicator of successfulness $+/$.

Separately for evaluation of competition functioning of goalie experts marked out the following technicaltactic actions and indicators: missed pucks; repelled pucks; percentage of repelled pucks; index of reliability (integral indicator, conv. un.).

In order to determine the most significant technical-tactic actions for highly qualified hockey players of different roles we conducted questioning of experts, hockey specialists (see fig.2). Concordance coefficient was $\mathrm{W}=0.76$, that witnesses about high concordance of experts, hockey specialists.

For example for winger experts related to the most significant technical tactic actions the following: thrown in pucks- $15 \%$, gained scores in match- $15 \%$, percentage of throws' realization- $14 \%$ total quantity of throws in net- 10 $\%$. For center forward, in opinion of experts, technical-tactic actions of priority are: thrown in pucks $-16 \%$, gained scores $-14 \%$, percentage of throws' realization $-13 \%$. 


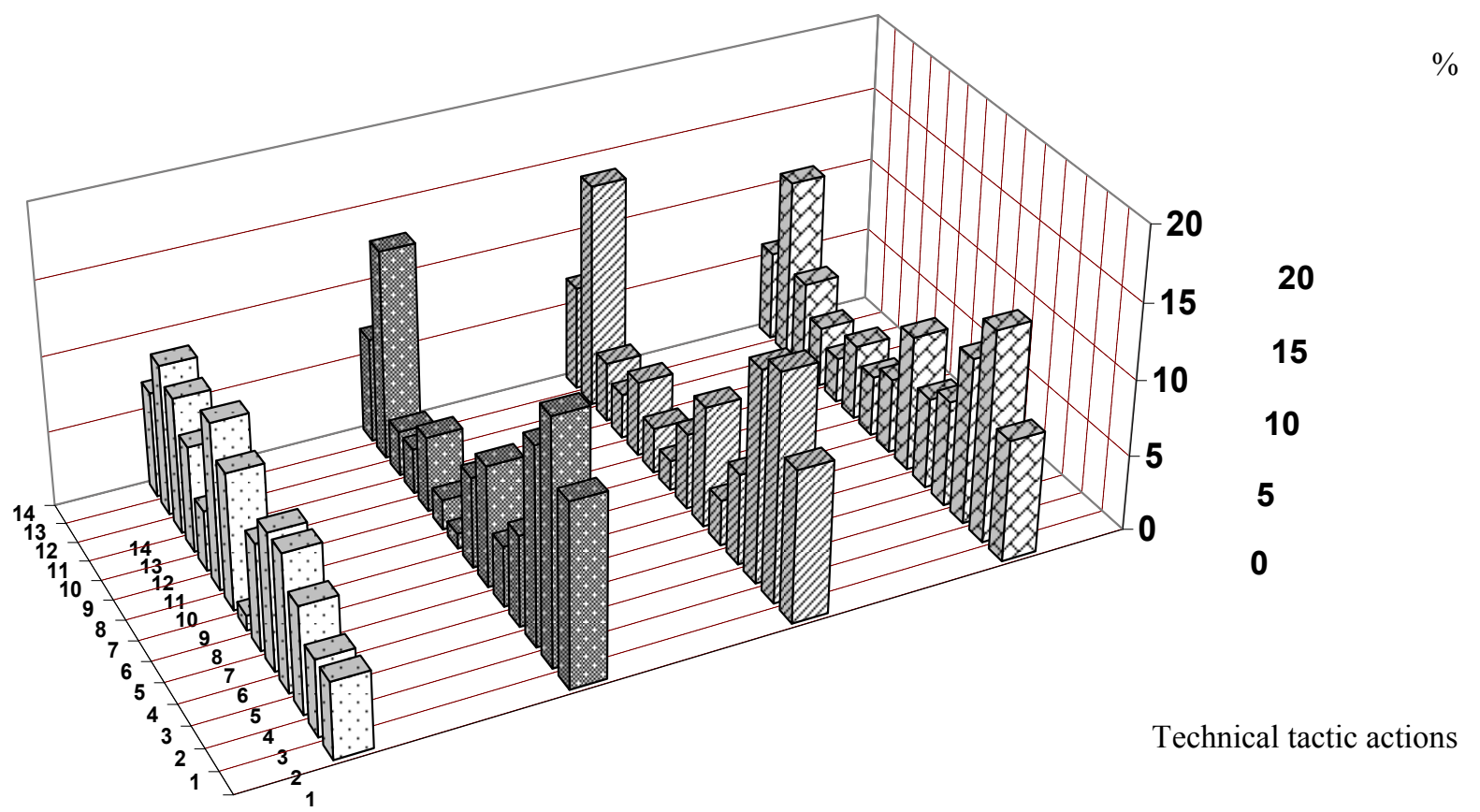

Fig.2. Significance of technical-tactic actions for highly qualified hockey players of different roles (in experts' opinion, $n=54)$ :
Без у방
ר进 winger;
center forward;
UTil back

1 - Throws in netl; 2 -thrown in pucks; 3 - percentage of throws' realization; 4 - power techniques; 5 penalty minutes; 6 -efficient passes; 7 -successful throws on field; 8 -repelled pucks; 9 -picking ups of puck; 10 obstacle to goalkeeper; 11 - support of partner; 12 -loss of puck; 13 - the gained scores; 14 - indicator of successfulness +/.

Among the most significant technical-tactic actions of a back, experts marked out the following: picking up of puck - $10 \%$, gained scores- $10 \%$, power techniques- $9 \%$, losses of puck repelled from net pucks $-9 \%$, indicator of successfulness (+/-) - $7 \%$. One of main tasks of backs is defense of own net, repelling of adversary's pucks, directed to net. During match backs shall conduct personal duels, use power techniques.

Also we separately conducted expert questioning about significance of actions in match for goalie. This way or another all technical-tactic actions and match indicators, which are used at present for evaluation of hockey goalie competition functioning, are connected with his skills in repelling throws to goal. From the offered by experts indicators the most significant are: missed pucks $-32 \%$, index of reliability -25 points, percentage of repelled pucks $-22 \%$, repelled throws in net- $21 \%$ (see fig. 3 ).

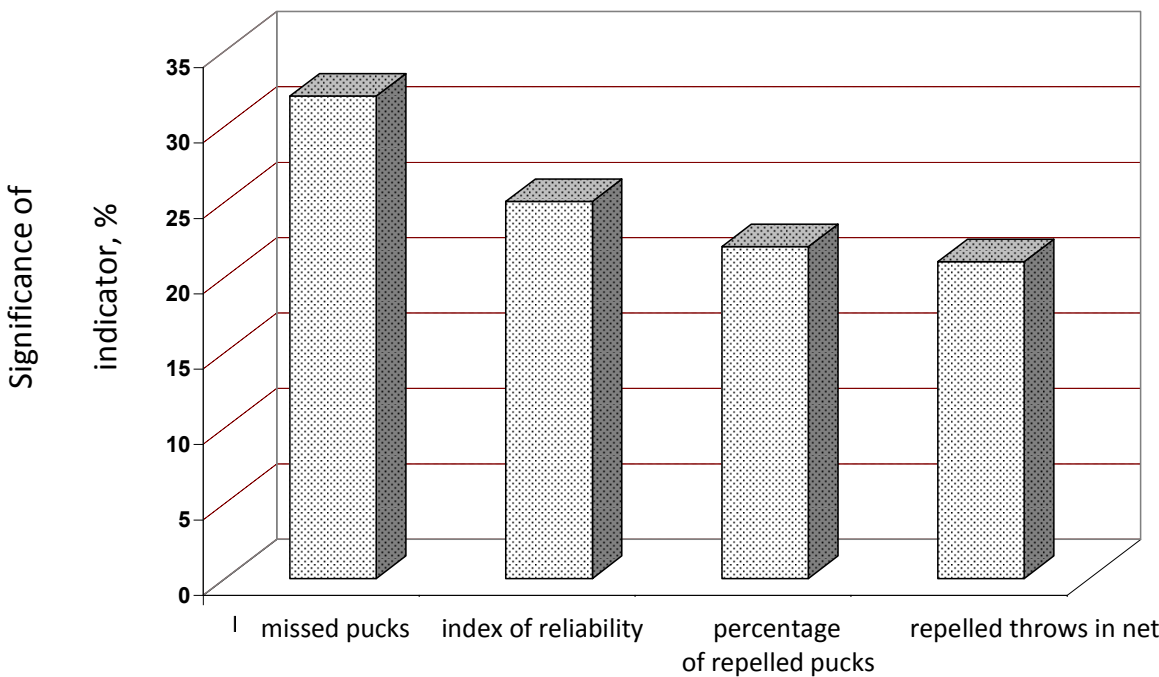

Fig.3. Significance of match indicators for highly qualified hockey goalkeeper (in experts' opinion, $n=54$ ): 
In specialists' opinion, good goalie shall have perfect reaction, ability to take correct position in front of hockey net and organize coordinated actions of partners in defense. Important qualities in hockey goalkeeper's actions are abilities for instant responding and anticipation.

\section{Conclusions:}

1. The conducted analysis of literature sources, pedagogic observations and questioning of experts permitted to systemize technical tactic actions, fulfilled by highly qualified hockey players in match and conventionally divide them into three relatively independent groups: 1) active attacking actions; 2) organizational-maneuvering actions; 3) active defensive actions; 4) actions of hockey goalie.

2. As a result of conducted exerts' questioning we determined the most informative indicators, which are recommended to be used for control and evaluation of hockey players' competition functioning: fulfilled throws in hockey net; thrown in pucks; percentage of realization of throws in net; fulfilled power techniques; penalty minutes for violation of rules; efficient passes of puck; successful throws on field; repelled from hockey net pucks; picked up pucks; obstacles for hockey goalie; support of partner; loss of puck; gained scores; indicator of successfulness (+/-). For hockey players of different roles expert marked out as technical tactic actions of first priority the following: for winger they are thrown in net pucks $-15 \%$, gained in match scores- $15 \%$, percentage of throws' realization- $14 \%$. For center forward: thrown in net pucks - Для 16\%, gained scores- $14 \%$, percentage of realization of throws in hockey net- $13 \%$. For backs: picking up of pucks- $10 \%$, gained scores- $10 \%$, power techniques- $9 \%$, потери шайбы - $9 \%$, repelled from net pucks- $9 \%$

The prospects of further researches imply working out of model characteristics of technical tactic actions of different roles' highly qualified hockey players as well as analysis of influence of personality's psychological features on hockey players' competition functioning.

\section{References:}

1. Ajrapet'ianc L.G. Pedagogicheskie osnovy planirovaniia i kontrolia uchebno-trenirovochnoj $i$ sorevnovatel'noj deiatel'nosti $v$ sportivnykh igrakh. Dokt.diss. [Pedagogical bases of planning and control for training and competitive activity in sports. Dokt. Diss.]. Moscow, 1992, 41 p. (in Russian)

2. Babushkin V.Z. Specializaciia v sportivnykh igrakh [Specialization in sports games]. Kiev, 1991,161 p. (in Russian)

3. Bezmylov N.N. Obosnovanie kompleksa informativnykh pokazatelej i opredelenie ikh prioritetnoj znachimosti dlia otbora kvalificirovannykh basketbolistov $\mathrm{v}$ komandu [Justification complex informative indicators and determining their priority importance to the selection of qualified basketball team]. Fizicheskoe vospitanie studentov, 2010, no.2, pp. 18-23. (in Russian)

4. Godik M.A., Skorodumova A.P. Kompleksnyj kontrol'v sportivnykh igrakh [Complex control in sports games]. Moscow, 2010, 336 p. (in Russian)

5. Keller V.S. Sorevnovatel'naia deiatel'nost'v sisteme sportivnoj podgotovki. Sovremennaia sistema sportivnoj podgotovki [Competitive activity in the athletic training]. Moscow, 1995, pp. 41-50. (in Russian)

6. Kozina Zh.L. Individualizaciia podgotovki sportsmenov v igrovykh vidakh sporta [Individualization of training of athletes in team sports]. Kharkov, 2009, 396 p. (in Russian)

7. Kostiukevich V. Integral'naia ocenka tekhniko-takticheskoj deiatel'nosti vysokokvalificirovannykh igrokov $\mathrm{v}$ khokkee na trave [Integral assessment of technical and tactical activity of highly skilled players in field of hockey]. Nauka v olimpijskom sporte, 2008, no.1, pp. 32-40. (in Russian)

8. Krasnikov A.A. Osnovy teorii sportivnykh sorevnovanij [Fundamentals of the theory of sports competitions]. Moscow, 2005, 160 p. (in Russian)

9. Latyshkevich L.A., Vorob'ev M.I., Bukhtij L.G. Problema povysheniia effektivnosti sorevnovatel'noj deiatel'nosti $\mathrm{v}$ sportivnykh igrakh [The problem of increasing the efficiency of competitive activity in sports games], Nauka $v$ olimpijskom sporte, 1997, no.2, pp. 13-16. (in Russian)

10. Platonov V.N. Sistema podgotovki sportsmenov v olimpijskom sporte [The system of preparation of sportsmen in Olympic sport], Kiev, Olympic Literature, 2004, 808 p. (in Russian)

11. Portnov Iu.M. Teoreticheskie $i$ nauchno-metodicheskie osnovy podgotovki kvalificirovannykh sportsmenov $v$ igrovykh vidakh sporta. Dokt.diss. [Theoretical and methodological bases of preparation of qualified athletes in team sports. Dokt. Diss.]. Moscow, 1989, 51 p. (in Russian)

12. Savenkov G.I. Psikhologicheskaia podgotovka sportsmena v sovremennoj sisteme sportivnoj trenirovki [Psychological training of athlete in the modern system of sports training]. Moscow, Physical Culture and Sport, 2006, 96 p. (in Russian)

13. Temchenko V.A. Registraciia, obrabotka i analiz pokazatelej sorevnovatel'noj deiatel'nosti v sportivnykh igrakh [Registration, processing and analysis of competitive activity in sports games]. Fizicheskoe vospitanie studentov tvorcheskikh special'nostej, 2006, no.2, pp. 37-48. (in Russian)

14. Shinkaruk O.A., Bezmilov M.M. Teoretiko-metodichni zasadi rozrobki ta vikoristannia model'nikh kharakteristik tekhniko-taktichnikh dij basketbolistiv visokoi kvalifikacii [Theoretical and methodological basis for the development and use of model performance technical and tactical basketball skill]. Teoriia $i$ metodika fizichnogo vikhovannia i sportu, 2013, no.2, pp. 35-44. (in Ukrainian)

15. Shustin B.N. Model'nye kharakteristiki sorevnovatel'noj deiatel'nosti. Sovremennaia sistema sportivnoj podgotovki [Model characteristics of competitive activity]. Moscow, 1995, pp. 226 - 237. 
16. Bompa T.O., Carrera M. Periodization training for sports. Chapmaign, Human Kinetics, 2005, 259 p.

17. Enciu S.L. Hockey. For children and juniors. Quidde book for young coaches. Romanicu Field Hockey Federation. 2001, 272 p.

18. Trninić S., Dizdar D. Performance Evaluation Criteria. Coll. Antropol. 2000, vol.24, no.1, pp. $217-234$.

19. Platonov V.N. Qualified Sportsmen Training. Moscow, Physical Culture and Sports, 1986, 255 p.

Information about the author:

Mikhnov A.P.: http://orcid.org/0000-0002-7179-1554;

kaupervud2022@mail.ru; National University of Physical

Education and Sport of Ukraine; Fizkultury str. 1, Kiev, 03680 , Ukraine.

Cite this article as: Mikhnov A.P. Rationale set of indicators and prioritize relevant to assess competitive activity of hockey players of high qualification of different roles. Physical education of students, 2015, no.1,pp. 31-35.http://dx.doi.org/10.15561/20755279.2015.0105

The electronic version of this article is the complete one and can be found online at: http://www.sportpedu.org.ua/html/arhive-e.html

This is an Open Access article distributed under the terms of the Creative Commons Attribution License, which permits unrestricted use, distribution, and reproduction in any medium, provided the original work is properly cited (http:/ creativecommons.org/licenses/by/3.0/deed.en).

Received: 12.11 .2014

Accepted: 12.12.2014; Published: 30.12 .2014 